Review

\title{
Noninvasive Assessment of Hepatitis C Virus Infected Patients Using Vibration-Controlled Transient Elastography
}

\author{
Mira Florea ${ }^{1,+}(\mathbb{D})$, Teodora Serban ${ }^{2, \dagger}$, George Razvan Tirpe ${ }^{3, \ddagger}$, Alexandru Tirpe ${ }^{4, \ddagger(1)}$ \\ and Monica Lupsor-Platon $2,5, *$ \\ 1 Community Medicine Department, Iuliu Hatieganu University of Medicine and Pharmacy, \\ 400012 Cluj-Napoca, Romania; miraflorea@umfcluj.ro \\ 2 Medical Imaging Department, Iuliu Hatieganu University of Medicine and Pharmacy, \\ 400012 Cluj-Napoca, Romania; serban.teodora8@gmail.com \\ 3 Department of Radiology and Medical Imaging, County Emergency Hospital Cluj-Napoca, \\ 3-5 Clinicilor Street, 400000 Cluj-Napoca, Romania; razvantirpe@gmail.com \\ 4 Research Center for Functional Genomics, Biomedicine and Translational Medicine, Iuliu Hatieganu \\ University of Medicine and Pharmacy, 23 Marinescu Street, 400337 Cluj-Napoca, Romania; altirpe@gmail.com \\ 5 Medical Imaging Department, Regional Institute of Gastroenterology and Hepatology, \\ 400162 Cluj-Napoca, Romania \\ * Correspondence: monica.lupsor@umcluj.ro \\ $+\quad$ M.F. and T.S. share the first co-authorship. \\ $\ddagger$ These authors have equal contribution to the work.
}

check for updates

Citation: Florea, M.; Serban, T.; Tirpe, G.R.; Tirpe, A.; Lupsor-Platon, M. Noninvasive Assessment of Hepatitis C Virus Infected Patients Using Vibration-Controlled Transient Elastography. J. Clin. Med. 2021, 10, 2575. https://doi.org/10.3390/ jcm10122575

Academic Editors: Maria Carla Liberto and Nadia Marascio

Received: 7 April 2021

Accepted: 8 June 2021

Published: 10 June 2021

Publisher's Note: MDPI stays neutral with regard to jurisdictional claims in published maps and institutional affiliations.

Copyright: (c) 2021 by the authors. Licensee MDPI, Basel, Switzerland. This article is an open access article distributed under the terms and conditions of the Creative Commons Attribution (CC BY) license (https:// creativecommons.org/licenses/by/ $4.0 /)$.

\begin{abstract}
Chronic infection with hepatitis $\mathrm{C}$ virus $(\mathrm{HCV})$ is one of the leading causes of cirrhosis and hepatocellular carcinoma (HCC). Surveillance of these patients is an essential strategy in the prevention chain, including in the pre/post-antiviral treatment states. Ultrasound elastography techniques are emerging as key methods in the assessment of liver diseases, with a number of advantages such as their rapid, noninvasive, and cost-effective characters. The present paper critically reviews the performance of vibration-controlled transient elastography (VCTE) in the assessment of HCV patients. VCTE measures liver stiffness (LS) and the ultrasonic attenuation through the embedded controlled attenuation parameter (CAP), providing the clinician with a tool for assessing fibrosis, cirrhosis, and steatosis in a noninvasive manner. Moreover, standardized LS values enable proper staging of the underlying fibrosis, leading to an accurate identification of a subset of $\mathrm{HCV}$ patients that present a high risk for complications. In addition, VCTE is a valuable technique in evaluating liver fibrosis prior to HCV therapy. However, its applicability in monitoring fibrosis regression after $\mathrm{HCV}$ eradication is currently limited and further studies should focus on extending the boundaries of VCTE in this context. From a different perspective, VCTE may be effective in identifying clinically significant portal hypertension (CSPH). An emerging prospect of clinical significance that warrants further study is the identification of esophageal varices. Our opinion is that the advantages of VCTE currently outweigh those of other surveillance methods.
\end{abstract}

Keywords: chronic hepatitis C; vibration controlled transient elastography; fibrosis; steatosis; hepatocellular carcinoma

\section{Introduction}

The global estimates of hepatitis $\mathrm{C}$ virus ( $\mathrm{HCV}$ ) infection appraised chronic hepatitis $\mathrm{C}(\mathrm{CHC})$ as one of the leading causes of cirrhosis and hepatocellular carcinoma (HCC), with an approximate global prevalence of $\mathrm{HCV}$ infection at $1.6 \%$ [1,2]. Specifically, CHC patients may silently develop cirrhosis in up to $20 \%$ of cases. In addition, patients with $\mathrm{CHC}$ and cirrhosis may develop HCC in up to $5 \%$ of cases per year [3]. HCV transmission routes are dependent on blood and blood products [4]. The diagnosis of HCV infection can be achieved through serologic assays and molecular RNA-based assays. In general terms, third generation serologic assays have a sensitivity of over $99 \%$ when CHC is suspected [4]. 
However, the silent progression of $\mathrm{CHC}$ towards cirrhosis prompts for new diagnostic means that can identify this pathological tendency early on the evolution axis. Liver fibrosis (LF) staging is paramount as it carries multiple roles-it is essential for the antiviral therapy, in the management of individuals after successful HCV treatment, and for prognosis purposes [5]. In addition, steatosis can accelerate liver fibrosis progression in HCV patients, and is associated with lower virologic response to antiviral therapy [6]. Although there is evidence of the contribution of ultrasound and even of artificial intelligence-enhanced US image analysis in steatosis quantification [7], new imaging techniques such as elastography are considered an essential add-on. The highly efficient direct-acting antiviral (DAA) therapies and noninvasive measures of liver fibrosis are two scientific advances that changed the management of patients with chronic HCV infection in the last decade [8].

Liver biopsy (LB) is an invasive method for staging fibrosis and grading steatosis and necroinflammatory activity [1]. It presents a number of drawbacks, including the risk of serious complications that may influence the patient acceptance rate and the lack of dynamic evaluation of liver fibrosis in time [9,10]. Although LB remains the reference standard for assessing necroinflammation and fibrosis, its limitations as an invasive procedure and requires repeated sampling, which has led to the use and development of several other noninvasive test as alternatives [11].

Conventional ultrasonography (US) (with or without contrast enhancement) is a noninvasive, cost-effective, widely available, and rapid technique that enables the examination of patients with chronic liver diseases (CLD) [12]. By evaluating structural changes, US proved to be particularly useful for the detection of cirrhosis and focal liver lesions (FLL) [12,13]. However, US fails to discern between lower stages of fibrosis, in which has led to the introduction of US elastography in order to overcome this drawback [14].

Vibration-controlled transient elastography (VCTE) is a novel, noninvasive, costefficient method for fibrosis staging using liver stiffness measurement (LSM) [10]. Furthermore, through the embedded Controlled Attenuation Parameter (CAP) tool, VCTE is able to simultaneously assess liver steatosis by estimating the total ultrasonic attenuation [15]. The current tendency of liver fibrosis assessment leans in favor of VCTE, as ultrasound elastography methods are becoming the standard of care in comparison to liver biopsy [1].

The present review aims to explore the current status of VCTE as noninvasive imaging assessment tool of HCV-infected patients through the lens of evidence-based medicine, underlining the differences between VCTE and conventional US.

\section{The Principle of Vibration-Controlled Transient Elastography (VCTE, TE)}

As previously mentioned, VCTE is a quantitative method for the noninvasive assessment of liver stiffness. It is composed of a device with readout-FibroScan ${ }^{\circledR}$ (Echosens, Paris, France)-and different types of probes (S, M and XL). Choosing the correct transducer, according to the circumference of the patients' thorax, is an important step in order to have a successful examination. While a circumference lower than $75 \mathrm{~cm}$ indicates the use of the $S$ probe, the $\mathrm{M}$ probe is indicated for a circumference of over $75 \mathrm{~cm}$. Furthermore, if the distance between the skin and liver capsule is greater than $25 \mathrm{~mm}$, the $\mathrm{XL}$ transducer is the preferred option. It is worth mentioning that the median liver stiffness is significantly lower with XL probe compared to the M probe [16]. 
The ideal VCTE examination takes place with a patient who has fasted for $3 \mathrm{~h}$ prior to the measurement $[17,18]$. Depending on the thickness of the abdominal wall, one of the handheld probes is chosen and, together with the applied conduction gel, the probe is placed intercostally overlying the right hepatic lobe [19-21]. The probe generates a vibration wave, which travels through the liver and simultaneously receives ultrasound waves, calculating liver stiffness, rendered in kilopascal $(\mathrm{kPa})$. In order to provide a median value of LS, ten successful measurements are required. LS can range widely between $2.5-75 \mathrm{kPa}$, with normal values being around $5 \mathrm{kPa}$. LS does not absolutely stage fibrosis like a biopsy would, but high values are significantly correlated with histology and are able to provide a risk estimate for advanced liver disease [22].

Simultaneously, the CAP (measured in $\mathrm{dB} / \mathrm{m}$ ) is calculated based on the attenuation of the ultrasound signal, with the purpose of evaluating the underlying liver steatosis in a noninvasive manner [23]. Chon et al. [24] suggested that the range of normal CAP values within the 5th-95th percentiles was $156.0-287.8 \mathrm{~dB} / \mathrm{m}$, with gender, body mass index, diabetes, and etiology independently affecting CAP values [25].

\section{Pathological Changes Influencing Liver Stiffness}

A comprehensive evaluation of the factors that increase liver stiffness is considered paramount. In a study by Lupsor et al. [26] that included $324 \mathrm{HCV}$ patients, the authors found a strong correlation between LS and different histopathological parameters such as fibrosis $(\mathrm{r}=0.759, p<0.0005)$, necroinflammatory activity $(\mathrm{r}=0.378, p<0.0005)$, and steatosis $(r=0.255, p<0.0005)$. Among these three, however, the stage of fibrosis is the single most important predictor.

Nevertheless, ingestion of food prior to LS measurement is another reason for increased $\mathrm{kPa}$ values. In a study by Arena et al. [17], LS was evaluated following a standardized meal in 125 confirmed $\mathrm{HCV}$ patients at different stages of fibrotic evolution. An elevation in $\mathrm{kPa}$ values was observed 15 to 45 minutes after ingestion of the meal and was higher among patients with increased stages of fibrosis $(p<0.001)$ and maximal among those with cirrhosis. Other factors that influence liver stiffness irrespective of fibrosis are mechanic cholestasis, central venous pressure and congestion, portal or arterial pressure, alcohol consumption, water retention, Valsalva and orthostatic maneuvers, as well as amyloidosis $[27,28]$.

A rise in LS values along with a rise in ALT levels can be detected in patients with hepatitis due to cellular swelling and cholestasis. Furthermore, the increased stiffness values identified in patients with relapsed chronic hepatitis are not only found due to fibrosis, but also due to the superimposed cellular intumescence [29]. In a study by Bota et al. [30], the LS cutoffs were significantly higher in patients with increased ALT levels between 1.1 and 5 -fold the standard value compared to those with normal ALT levels, $12.3 \mathrm{kPa}$ versus $9.1 \mathrm{kPa}$, respectively. Consequently, caution must be taken when assessing liver stiffness in patients with increased ALT values because there is a risk of overestimating the stage of fibrosis [16]. 


\section{Fibrosis Assessment by VCTE in HCV-Infected Patients}

Among patients with $\mathrm{CHC}$, determining liver fibrosis stage is essential for prognosis, follow-up, and antiviral therapy [5]. The European Federation of Societies for Ultrasound in Medicine and Biology (EFSUMB) guidelines outline that the two clinically relevant endpoints in $\mathrm{HCV}$ patients are the detection of significant fibrosis and, above anything else, the detection of cirrhosis [27]

As previously implied, the widely available US method fails to discern fibrosis in its early stages, which led to the introduction of novel elastography technologies. In fact, a recent study by Zhang et al. [13] found VCTE to be superior to US for the detection of significant fibrosis (AUROC, 0.84 versus $0.73 ; p=0.02$ ), advanced fibrosis (AUROC, 0.95 versus $0.76 ; p<0.001$ ), and cirrhosis (AUROC, 0.96 versus $0.71 ; p<0.001$ ) in a cohort of 94 patients with chronic hepatitis B and nonalcoholic fatty liver disease. In addition, the combination of VCTE and US did not increase the diagnostic accuracy for neither of these stages, compared to VCTE alone. However, their association significantly improved the specificity $(95.7 \%$ versus $76.6 \%, p<0.001)$ and positive predictive value $(94.3 \%$ versus $77.1 \%$, $p=0.002$ ) in contrast to VCTE alone. Similar results were observed by Wang et al. [31] in 320 patients with chronic viral hepatitis. Regarding other noninvasive methods, an evidence-based analysis concluded that neither FibroTest, nor acoustic radiation force impulse were superior to VCTE [32].

$\mathrm{HCV}$ infected patients are the first to have benefited from VCTE. Several studies reported excellent diagnostic accuracy of VCTE for the detection of fibrosis in HCV patients. As exemplified in Table 1, LS significantly correlates with the degree of liver fibrosis assessed by LB, even if some adjacent stages tend to overlap [10,26,33-43]. The AUROC values range from 0.838 to 0.936 for incipient fibrosis $(\geq F 1), 0.690$ to 0.91 for significant fibrosis ( $\geq$ F2), 0.737 to 0.99 for advanced fibrosis ( $\geq F$ 3), and 0.852 to 0.99 for cirrhosis (F4) prediction, at cutoff values of $5.3-5.5 \mathrm{kPa}(\geq \mathrm{F} 1), 4.5-8.8 \mathrm{kPa}(\geq \mathrm{F} 2), 9.1-11 \mathrm{kPa}(\geq \mathrm{F} 3)$ and $11.3-16.9 \mathrm{kPa}(\mathrm{F} 4)$, respectively. These values range significantly, mainly because of the varying prevalence of fibrosis stage in each study group along with the particular diagnostic aims of the investigation [44]. Thereby, the already defined cutoff values may not be applicable in all groups of patients, with different prevalence of fibrosis or diagnostic purposes [16]. 


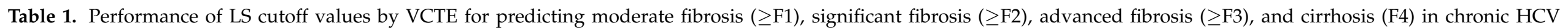
infected patients.

\begin{tabular}{|c|c|c|c|c|c|c|c|c|c|c|c|c|}
\hline \multirow{2}{*}{$\begin{array}{c}\text { Fibrosis Stage } \\
\text { Study }\end{array}$} & \multicolumn{3}{|c|}{$\geq \mathbf{F} 1$} & \multicolumn{3}{|c|}{$\geq \mathbf{F} 2$} & \multicolumn{3}{|c|}{$\geq \mathbf{F} 3$} & \multicolumn{3}{|c|}{ F4 } \\
\hline & Cutoff (kPa) & AUROC & $\begin{array}{c}\text { Se/Sp } \\
(\%)\end{array}$ & $\begin{array}{l}\text { Cutoff } \\
\text { (kPa) }\end{array}$ & AUROC & $\begin{array}{c}\text { Se/Sp } \\
(\%)\end{array}$ & $\begin{array}{l}\text { Cutoff } \\
(\mathrm{kPa})\end{array}$ & AUROC & $\begin{array}{c}\text { Se/Sp } \\
(\%)\end{array}$ & $\begin{array}{l}\text { Cutoff } \\
(\mathrm{kPa})\end{array}$ & AUROC & $\mathrm{Se} / \mathrm{Sp}(\%)$ \\
\hline Castera et al. [35] $(n=183)$ & $\mathrm{N} / \mathrm{S}$ & $\mathrm{N} / \mathrm{S}$ & $\mathrm{N} / \mathrm{S}$ & 7.1 & 0.83 & $67 / 89$ & 9.5 & 0.90 & $73 / 91$ & 12.5 & 0.95 & $87 / 91$ \\
\hline Carrion et al. [45] $(n=169)$ & $\mathrm{N} / \mathrm{S}$ & $\mathrm{N} / \mathrm{S}$ & $\mathrm{N} / \mathrm{S}$ & 8.50 & 0.90 & $90 / 81$ & $\mathrm{~N} / \mathrm{S}$ & 0.93 & $\mathrm{~N} / \mathrm{S}$ & 12.50 & 0.98 & $100 / 87$ \\
\hline Ziol et al. [34] $(n=327)^{1}$ & $\mathrm{~N} / \mathrm{S}$ & $\mathrm{N} / \mathrm{S}$ & $\mathrm{N} / \mathrm{S}$ & 8.80 & $\begin{array}{l}0.79 \\
0.81\end{array}$ & $56 / 91$ & 9.60 & $\begin{array}{l}0.91 \\
0.95\end{array}$ & $86 / 85$ & 14.60 & $\begin{array}{l}0.97 \\
0.99\end{array}$ & $86 / 96$ \\
\hline De Ledinghen et al. [36] $(n=77)^{2}$ & $\mathrm{~N} / \mathrm{S}$ & $\mathrm{N} / \mathrm{S}$ & $\mathrm{N} / \mathrm{S}$ & 4.5 & 0.72 & $93.2 / 17.9$ & $\mathrm{~N} / \mathrm{S}$ & $\mathrm{N} / \mathrm{S}$ & $\mathrm{N} / \mathrm{S}$ & 11.8 & 0.97 & $100 / 92.7$ \\
\hline Sporea et al. [46] $(n=191)$ & $\mathrm{N} / \mathrm{S}$ & $\mathrm{N} / \mathrm{S}$ & $\mathrm{N} / \mathrm{S}$ & 6.8 & 0.733 & $59.6 / 93.3$ & $\mathrm{~N} / \mathrm{S}$ & $\mathrm{N} / \mathrm{S}$ & $\mathrm{N} / \mathrm{S}$ & $\mathrm{N} / \mathrm{S}$ & $\mathrm{N} / \mathrm{S}$ & $\mathrm{N} / \mathrm{S}$ \\
\hline Nitta et al. [43] $(n=165)$ & $\mathrm{N} / \mathrm{S}$ & $\mathrm{N} / \mathrm{S}$ & $\mathrm{N} / \mathrm{S}$ & 7.1 & 0.87 & $80.8 / 80.3$ & 9.6 & 0.91 & $87.7 / 82.4$ & $11.6-16.9$ & 0.93 & 62.5-91.7/78.9-91.5 \\
\hline Sanchez-Conde et al. [42] $(n=100)$ & $\mathrm{N} / \mathrm{S}$ & $\mathrm{N} / \mathrm{S}$ & $\mathrm{N} / \mathrm{S}$ & 7 & 0.80 & $76.7 / 75.4$ & 11 & 0.93 & $80 / 90.6$ & 14 & 0.99 & $100 / 93.5$ \\
\hline $\begin{array}{l}\text { Reiberger et al. [47] } \\
\quad(n=290)\end{array}$ & $\mathrm{N} / \mathrm{S}$ & $\mathrm{N} / \mathrm{S}$ & $\mathrm{N} / \mathrm{S}$ & 7.2 & 0.690 & $73.3 / 77.4$ & 9.6 & 0.737 & $86.9 / 82.9$ & 12.1 & 0.904 & $84.8 / 86.8$ \\
\hline Zarski et al. [38] $(n=382)$ & $\mathrm{N} / \mathrm{S}$ & $\mathrm{N} / \mathrm{S}$ & $\mathrm{N} / \mathrm{S}$ & 5.2 & 0.82 & $96.6 / 34.8$ & $\mathrm{~N} / \mathrm{S}$ & $\mathrm{N} / \mathrm{S}$ & $\mathrm{N} / \mathrm{S}$ & 12.9 & 0.93 & $76.8 / 89.6$ \\
\hline Lupsor et al. [10] $(n=1202)$ & 5.3 & 0.879 & $84.99 / 73.21$ & 7.4 & 0.889 & $80.32 / 83 / 97$ & 9.1 & 0.941 & $88.8 / 88.3$ & 13.2 & 0.970 & $93.75 / 93.31$ \\
\hline Yoneda et al. [40] $(n=102)$ & 5.5 & 0.838 & $84.6 / 71.4$ & 7.8 & 0.906 & $77.9 / 90.0$ & 10.4 & 0.952 & $88.1 / 91.1$ & 11.3 & 0.907 & $90.0 / 83.8$ \\
\hline Njei et al. $[41]^{*}(n=756)^{2}$ & $\mathrm{~N} / \mathrm{S}$ & $\mathrm{N} / \mathrm{S}$ & $\mathrm{N} / \mathrm{S}$ & $4.5-7.2$ & $\mathrm{~N} / \mathrm{S}$ & $97 / 64$ & $\mathrm{~N} / \mathrm{S}$ & $\mathrm{N} / \mathrm{S}$ & $\mathrm{N} / \mathrm{S}$ & $11.8-14.6$ & $\mathrm{~N} / \mathrm{S}$ & $90 / 87$ \\
\hline
\end{tabular}

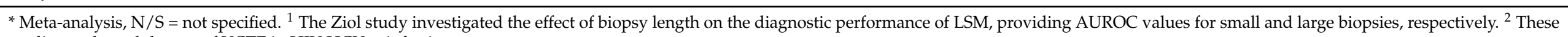
studies evaluated the use of VCTE in HIV-HCV coinfection. 


\section{VCTE Performance for Cirrhosis Evaluation in HCV Patients}

\subsection{Diagnosis of Cirrhosis by VCTE}

One of the greatest benefits of VCTE is the noninvasive diagnosis of cirrhosis. As previously implied, VCTE performs better at evaluating cirrhosis rather than evaluating fibrosis stages [48]. In the Talwalkar meta-analysis [49], the pooled estimates for sensitivity (Se) and specificity (Sp) for cirrhosis were $87 \%$ and $91 \%$, respectively. However, the diagnostic threshold bias was an important cause of heterogeneity for pooled results. In 2007, Shaheen et al. [50] provided summary estimates for cirrhosis diagnosis with a Se and Sp of $85.6 \%$ and $93.2 \%$, respectively, for LS exceeding $12.5 \mathrm{kPa}$ and AUROC values of 0.95 . In another meta-analysis by Stebbing et al. [51], the cutoff value of $15.08 \mathrm{kPa}$ had $84.45 \%$ Se and $94.69 \%$ Sp. Tsochatzis et al. [52] evaluated the VCTE accuracy for cirrhosis prediction and reported a summary Se and Sp of $83 \%$ and $89 \%$, respectively, at a diagnostic threshold of $15 \pm 4 \mathrm{kPa}$. The latest meta-analysis by Ying et al. [53], demonstrated high Se (84\%) and Sp (90\%) of VCTE for assessing liver cirrhosis in HCV patients. These results suggest that VCTE performs better at ruling out rather than ruling in cirrhosis, with a negative predictive value greater than $90 \%[35,36,54]$.

In contrast, regarding US there are conflicting results. The US scoring system (USSS) proposed by Moon et al. [55] seemed to surpass VCTE for the diagnosis of overt cirrhosis, providing $89.2 \%$ Se and $69.4 \%$ Sp for USSS $\geq 6$, while LSM $\geq 17.4 \mathrm{kPa}$ had $77.6 \%$ Se and $61.4 \%$ Sp. Nevertheless, the Moon study had several limitations, considering that diverse etiologies included in the study provided lower AUROC values for LSM (0.729) than usual. Berzigotti et al. [56] found that among subjects with presumed cirrhosis, US is the better choice to diagnose cirrhosis, whereas VCTE is the preferred method to rule it out. Their combination increased the diagnostic accuracy, contrasting the results of the Zhang [13] and Wang [31] studies.

\subsection{Screening for Portal Hypertension}

Portal hypertension $(\mathrm{PH})$ is a common clinical syndrome of CLD, hemodynamically defined by increased portal venous pressure and a hyperdynamic state $[57,58]$. In the early, compensated phases of cirrhosis, $\mathrm{PH}$ is mainly a result of intrahepatic resistance to portal blood flow due to morphological changes characterized by fibrosis [59]. Subsequently, as the disease progresses, the increase in portal pressure gradient leads to severe complications, consisting of portosystemic collaterals and varices [58]. In cirrhosis, hepatic venous pressure gradient (HVPG) is the standard PH assessment method, but it is invasive and expensive. A HVPG value greater than $10 \mathrm{mmHg}$ represents the threshold for clinically significant portal hypertension (CSPH), a stage where PH complications might arise [58]. For these patients, compensated advanced CLD (cACLD) is an alternative term recommended by the Baveno VI criteria [60], mainly to indicate that the fibrosis progression is a continuum spectrum among asymptomatic patients.

Abdominal US is the primary imaging technique widely used for liver, spleen and portal venous system evaluation, since it can identify PH features, including splenomegaly, portal vein system dilatation, ascites, and portosystemic abdominal collaterals [61,62]. In particular, the incorporation of color and power Doppler enabled the appraisal of the left gastric vein (LGV) hemodynamics, the damping index, and the splenic Doppler pulsatility index [63-65]. Of note is the Lee study which reported higher diagnostic accuracy $(\mathrm{AUC}=0.873)$ for splenic arterial resistive index compared to the accuracy of LSM (AUC $=0.745)$ in a cohort of 47 patients [66]. Nonetheless, existing data is insufficient to recommend Doppler measurements as a trustworthy substitute for HVPG [67]. 
VCTE proved to be an excellent diagnostic tool for identifying CSPH with a hierarchical summary receiver operating characteristic (HSROC) value of 0.93 , reported in the Shi meta-analysis [59]. Table 2 summarizes the results of studies regarding the accuracy of LSM for the prediction of preclinical $\mathrm{PH}, \mathrm{CSPH}$, and severe $\mathrm{PH}(\mathrm{SPH})$. Carrion et al. [45] were the first to report the significant correlation between LSM and HVPG (Pearson coefficient, 0.84; $p<0.001)$ among patients with HCV recurrence after liver transplant. Over time, these results were confirmed by prospective and retrospective studies in patients with CLD [39,47,59,68-74]. Even though Schwabl et al. [39] concluded that the etiology was not a significant confounder for the correlation between LSM and HVPG, we decided to emphasize within our table the $\mathrm{HCV}$ positive subgroup for integrative purposes [75-78]. Overall, the AUROC ranged from 0.786 to 0.93 for a threshold of 8 to $8.74 \mathrm{kPa}$ for preclinical $\mathrm{PH}, \mathrm{AUROC} 0.74$ to 0.99 for $\mathrm{CSPH}$ with the corresponding cutoff values ranging from 13.6 to $21.6 \mathrm{kPa}$, whilst SPH-related AUROC ranged from 0.721 to 0.92 with the associated cutoff values of 17.6 to $24.5 \mathrm{kPa}$. These results suggest that, even if the correlation between the two parameters does not allow accurate HVPG estimation, LS has great discriminative power for the presence of CSPH [27]. Recently, a multicenter study of 5648 patients proposed a novel set of cutoff values of $<7$ and $>12 \mathrm{kPa}$ for excluding and diagnosing compensated advanced liver disease. Lowering the dual threshold initially proposed by the Baveno VI consensus provided excellent Se (91\%) for ruling out and Sp (92\%) for ruling in cACLD, safely reducing the use of LB [60]. 
Table 2. Accuracy of LSM for the prediction of preclinical $\mathrm{PH}, \mathrm{CSPH}$, and SPH.

\begin{tabular}{|c|c|c|c|c|c|c|c|c|c|c|}
\hline \multicolumn{2}{|c|}{ Grade of Portal Hypertension (PH) } & \multicolumn{3}{|c|}{ Preclinical $\mathrm{PH}(\geq 5 \mathrm{mmHg})$} & \multicolumn{3}{|c|}{ Clinically Significant PH ( $\geq 10$ mmHg) } & \multicolumn{3}{|c|}{ Severe PH ( $\geq 12 \mathrm{mmHg}$ ) } \\
\hline Study & $\begin{array}{l}\text { Correlation } \\
\text { Coefficient }\end{array}$ & Cutoff $(\mathbf{k P a})$ & AUROC & Se/Sp (\%) & Cutoff (kPa) & AUROC & Se/Sp (\%) & $\begin{array}{c}\text { Cutoff } \\
(\mathrm{kPa})\end{array}$ & AUROC & Se/Sp (\%) \\
\hline Carrion et al. [45] $(n=129)^{1 *}$ & 0.84 & 8.74 & 0.93 & $90 / 81$ & $\mathrm{~N} / \mathrm{S}$ & 0.94 & $\mathrm{~N} / \mathrm{S}$ & $\mathrm{N} / \mathrm{S}$ & $\mathrm{N} / \mathrm{S}$ & $\mathrm{N} / \mathrm{S}$ \\
\hline Vizzutti et al. [75] $(n=61) *$ & 0.81 & $\mathrm{~N} / \mathrm{S}$ & $\mathrm{N} / \mathrm{S}$ & $\mathrm{N} / \mathrm{S}$ & 13.6 & 0.99 & $97 / 92$ & 17.6 & 0.92 & $94 / 81$ \\
\hline Bureau et al. [76] $(n=150){ }^{*}$ & 0.858 & $\mathrm{~N} / \mathrm{S}$ & $\mathrm{N} / \mathrm{S}$ & $\mathrm{N} / \mathrm{S}$ & 21 & 0.971 & $89.9 / 93.2$ & $\mathrm{~N} / \mathrm{S}$ & $\mathrm{N} / \mathrm{S}$ & $\mathrm{N} / \mathrm{S}$ \\
\hline $\begin{array}{l}\text { Lemoine et al. [77] } \\
\qquad(n=44) *\end{array}$ & 0.46 & $\mathrm{~N} / \mathrm{S}$ & $\mathrm{N} / \mathrm{S}$ & $\mathrm{N} / \mathrm{S}$ & 20.5 & $0.76 \pm 0.07$ & $63 / 70$ & $\mathrm{~N} / \mathrm{S}$ & $\mathrm{N} / \mathrm{S}$ & $\mathrm{N} / \mathrm{S}$ \\
\hline $\begin{array}{l}\text { Sanchez-C. et al. [78] } \\
\qquad(n=38)^{2 *}\end{array}$ & 0.46 & $\mathrm{~N} / \mathrm{S}$ & $\mathrm{N} / \mathrm{S}$ & $\mathrm{N} / \mathrm{S}$ & 14 & 0.80 & $92.86 / 50$ & 23 & 0.80 & $82.61 / 66.67$ \\
\hline Reiberger et al. [47] $(n=390)$ & 0.838 & 8 & 0.830 & $95.3 / 71$ & 18 & 0.892 & $80.3 / 86.9$ & 20 & 0.899 & $84.4 / 86.5$ \\
\hline Llop et al. [68] $(n=52)^{\#}$ & 0.646 & $\mathrm{~N} / \mathrm{S}$ & $\mathrm{N} / \mathrm{S}$ & $\mathrm{N} / \mathrm{S}$ & $\begin{array}{c}\text { Rule out: } 13.6 \\
\text { Rule in: } 21\end{array}$ & 0.857 & $\begin{array}{c}88 / 61 \\
42 / 100\end{array}$ & $\mathrm{~N} / \mathrm{S}$ & $\mathrm{N} / \mathrm{S}$ & $\mathrm{N} / \mathrm{S}$ \\
\hline Schwabl et al. [39] $(n=188)^{\#}$ & 0.846 & $\mathrm{~N} / \mathrm{S}$ & $\mathrm{N} / \mathrm{S}$ & $\mathrm{N} / \mathrm{S}$ & 16.1 & 0.957 & $94.8 / 86.9$ & $\mathrm{~N} / \mathrm{S}$ & $\mathrm{N} / \mathrm{S}$ & $\mathrm{N} / \mathrm{S}$ \\
\hline Hong et al. [69] $(n=59)^{\#}$ & 0.496 & $\mathrm{~N} / \mathrm{S}$ & $\mathrm{N} / \mathrm{S}$ & $\mathrm{N} / \mathrm{S}$ & 21.95 & 0.851 & $82.5 / 73.7$ & 24.25 & 0.877 & $82.9 / 70.8$ \\
\hline Kitson et al. [71] $(n=95)^{\#}$ & $\mathrm{~N} / \mathrm{S}$ & $\mathrm{N} / \mathrm{S}$ & $\mathrm{N} / \mathrm{S}$ & $\mathrm{N} / \mathrm{S}$ & 29.0 & 0.900 & $71.9 / 100$ & $\mathrm{~N} / \mathrm{S}$ & $\mathrm{N} / \mathrm{S}$ & $\mathrm{N} / \mathrm{S}$ \\
\hline Zykus et al. [72] $(n=107)^{\#}$ & 0.75 & $\mathrm{~N} / \mathrm{S}$ & $\mathrm{N} / \mathrm{S}$ & $\mathrm{N} / \mathrm{S}$ & 17.4 & 0.949 & $88 / 87.5$ & 20.6 & 0.915 & $82.8 / 80$ \\
\hline Procopet et al. [73] $(n=55)^{\#}$ & 0.699 & $\mathrm{~N} / \mathrm{S}$ & $\mathrm{N} / \mathrm{S}$ & $\mathrm{N} / \mathrm{S}$ & $19.0 \pm 13.3$ & 0.926 & $\mathrm{~N} / \mathrm{S}$ & $\mathrm{N} / \mathrm{S}$ & $\mathrm{N} / \mathrm{S}$ & $\mathrm{N} / \mathrm{S}$ \\
\hline Kumar et al. [74] $(n=326)$ & 0.361 & $\mathrm{~N} / \mathrm{S}$ & 0.786 & $\mathrm{~N} / \mathrm{S}$ & 21.6 & 0.74 & $79 / 67$ & $\mathrm{~N} / \mathrm{S}$ & 0.721 & $\mathrm{~N} / \mathrm{S}$ \\
\hline
\end{tabular}

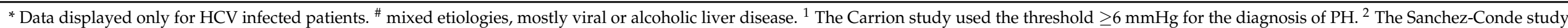

evaluated correlation between LSM and HVPG in HIV-HCV coinfection. 


\subsection{Prognostic Significance of Liver Stiffness in Patients with HCV Cirrhosis}

There is growing evidence to support the use of VCTE for risk stratification and prognosis [27] even in HCV cirrhosis. In a study of 1457 CHC patients, LS had stronger prognostic value for overall 5-year mortality compared to histological fibrosis staging [79]. In addition, LSM by VCTE has been validated as a prognostic quantitative marker for developing liver related complications, including esophageal varices (EV), variceal bleeding, hepatic decompensation, and HCC [79-82]. Recent data suggests that liver and spleen stiffness correlate considerably with HVPG among cirrhotic patients. In fact, spleen stiffness seems to be superior to LS for the prediction of $\mathrm{PH}$ and can even predict the late recurrence of HCC [83-85].

\subsubsection{Prediction of Esophageal Varices (EV) and Variceal Hemorrhage by VCTE}

In the past years, several studies sought to discover LS accuracy for predicting the presence and size of EV $[35,70,75,76,78,86]$. In general terms, the greater the LS value-the higher the risk of the patient to present $\mathrm{EV}$ and an increased degree of $\mathrm{EV}$, respectively [80]. However, as illustrated by Kim et al. [80], the cutoff values vary widely among studies and VCTE accuracy is still inappropriate to replace HVPG or upper GI endoscopy in screening for EV presence or determining their grade [27,48]. However, it should be mentioned that there were no noninvasive methods that proved to be satisfactorily enough. Even if several studies [64] found that LGV hepatofugal flow substantially correlates with EV, Doppler parameters are still unsuited to be a surrogate for esophagogastroduodenoscopy or HVPG, mostly as a result of significant inter-observer variability [67]. The current reference standard for the detection and classification of EV remains the esophagogastroduodenoscopy procedure, in spite of being an invasive and expensive method [67]. Nonetheless, VCTE should be used as an initial noninvasive method for selecting patients in whom these invasive procedures are indicated [48]. Recent data suggests that the combination between LS, spleen dimensions, and platelet count significantly improves the diagnostic accuracy of EV [87]. In fact, according to the latest recommendations of the Baveno VI guidelines, upper GI endoscopy can be safely avoided among patients with a LS value of $<20 \mathrm{kPa}$ and a platelet count greater than $150 \mathrm{G} / \mathrm{L}$ [88].

\subsubsection{The Prognostic Value of VCTE for HCC Development Prediction}

In patients with CLD, abdominal US is the first-line investigation for the detection and characterization of FLLs and the main screening tool for HCC with $51-87 \%$ Se and 80-100\% Sp [89-91]. The add-on of US contrast agents improved the overall diagnostic accuracy of conventional US, offering comparable performance to magnetic resonance imaging or computed tomography for FLLs evaluation [92]. However, even though US significantly improves HCC surveillance, it lacks prognostic power. Increasing evidence implies that noninvasive methods, such as VCTE, are not solely a substitute for LB, but also predictive for liver-related complications, in particular HCC development [48]. It is well known that the degree of fibrosis is by far the strongest risk factor for developing $\mathrm{HCC}$ in $\mathrm{HCV}$ patients [93]. A decade ago, Masuzaki et al. [94] were the first to describe the relationship between LS and HCC incidence in a Japanese cohort of $866 \mathrm{CHC}$ patients. The hazard ratio (HR) for HCC incidence was 16.7, 20.9, 25.6 and 45.5 for LS values of $10.1-15.0 \mathrm{kPa}, 15.2-20.0 \mathrm{kPa}, 20.1-25.0 \mathrm{kPa}$, and $>25.0 \mathrm{kPa}$, respectively $(p<0.001)$. Other longitudinal prospective studies evaluated the prognostic performance of VCTE for the prediction of HCC development in $\mathrm{HCV}$ patients, with cutoff values ranging between $12-50 \mathrm{kPa}$ [81,95-99]. In addition, Feier et al. [96] surprisingly found that an IQR exceeding 39\% of median LSM is another adequate indicator and essential predictor for the presence of HCC. Nonetheless, in order to confirm whether LS can actually foresee liver-related complications, these results require further validation through prospective studies conducted on large cohorts. In case these results are validated and standardized, VCTE might become an efficient method for the noninvasive screening of patients with CLD, with a possibility to classify them in different risk categories [16]. An interesting 
point to make is that the elastography parameter already provided effective risk prediction models, especially in patients with chronic hepatitis B infection [100-104]. However, existing literature does not provide any prediction model for HCV-related HCC risk.

Following the availability and efficacy of direct-acting antivirals (DAAs), several studies sought to elucidate their capability of reducing the HCC risk, and whether VCTE might become helpful in objectifying it. Some studies and one meta-analysis reported that the risk of de novo HCC development is similar or even diminished in the subgroup receiving antiviral treatment, compared to the general population [105-109]. However, the absolute risk in patients with cirrhosis remains high, regardless of therapy, which is why this subset of patients should be considered for ongoing HCC surveillance [110]. Elastography facilitates dynamic prediction of HCC, especially before and after the antiviral treatment. In terms of independent risk factors, increased baseline LS and other noninvasive markers of fibrosis, as well as a less than $30 \%$ decrease in LS, correlate significantly with the risk of developing HCC [111,112]. In addition, Ioannou et al. [113] developed and internally validated models that estimate the risk of HCC development after DAA therapy, improving HCC surveillance efforts. Nonetheless, their prediction models based on cirrhosis and sustained viral response (SVR) require further international endorsement. In a combined case report-literature review, Strazzulla et al. [114] described a particular case of recurrent $\mathrm{HCC}$ after successful DAA treatment in a $\mathrm{HCV}$ positive 53-year old patient that received liver transplantation. Although the literature is rather scarce, VCTE may also prove useful in evaluating liver disease progression towards HCC in HCV patients receiving liver transplantation [115].

\section{VCTE Use for Longitudinal Monitoring in Detecting Fibrosis Regression and Predicting Complication Risk after Achieving Sustained Viral Response}

As previously mentioned, the main endpoints in $\mathrm{CHC}$ patients are the detection of significant fibrosis ( $\geq F$ 2) and cirrhosis (F4), which have been the definitive indication of antiviral therapy for a long time [27]. However, due to the large availability of highly efficient DAAs, it is expected that significant fibrosis will no longer be a critical decisionmaking endpoint among these subjects [48].

VCTE, serving as a novel noninvasive method for fibrosis assessment, facilitates the longitudinal evaluation of HCV patients, before and after antiviral treatment. However, fibrosis and $\mathrm{PH}$ regression in patients with treated HCV-related cirrhosis is still a debatable subject [116]. Several studies explored the dynamics of LS in patients receiving antiviral therapy (interferon based/interferon-free therapies), concluding that the LS values decreased significantly in those with SVR [111,117-129]. Most of these studies showed better improvement of LS among patients with higher pre-treatment fibrosis stages [111,117-122,129]. However, Persico et al. [124] found that EV of any size anticipated a lack of LS improvement. A study by Chan et al. [125] reported that a baseline elevated ALT was independently associated with a reduction of LS beyond 30\%. As assumed by some researchers, this might come as a result of substantial decrease of liver inflammation, rather than fibrosis regression, at the end of the antiviral therapy [116,128,130-132]. Nonetheless, several reports showed that liver fibrosis reverses in approximately one third to nearly half of CHC patients [133]. Of note is the D'Ambrosio study, which found significant cirrhosis regression by LB in $61 \%$ of individuals with HCV-related cirrhosis [134].

\section{Controlled Attenuation Parameter (CAP) for the Noninvasive Evaluation of Steatosis in HCV-Infected Patients}

Besides fibrosis, steatosis is another common histological feature in HCV patients, especially those infected with genotype 3 [135]. Viral contamination is an independent risk factor for fat accumulation in HCV patients, along with obesity, type II diabetes mellitus, and alcohol consumption. Steatosis was found to be 1.5-2.5 times more prevalent among these subjects than in the general population [136]. In fact, several studies reported that steatosis might increase fibrosis progression and the risk of HCC development while 
lowering the response rate to antiviral treatment [137-140]. Therefore, steatosis assessment in $\mathrm{HCV}$ positive individuals is of great importance.

At present, abdominal conventional US is the most readily available, simple and cost-effective technique for steatosis appraisal in clinical setting [141]. A 2011 meta-analysis by Hernaez et al. [142] confirmed that B-mode US is a reliable method for steatosis assessment in comparison to liver biopsy. Among 4720 patients, liver US provided 84.8\% Se (95\% CI: 79.5-88.9), 93.6\% Sp (95\% CI: 87.2-97.0) and AUROC of 0.93 (95\% CI: 0.91-0.95) for moderate to severe steatosis detection. However, its sensitivity lowers when less than $30 \%$ of the hepatocytes are affected. Besides, it remains a subjective method, resulting in high variability and low reproducibility [141]. The introduction of the hepatorenal Index (HRI) sought to overcome this drawback, providing excellent diagnostic precision for the diagnosis of steatosis (>5\%) with AUROC of $0.99,100 \%$ Se and $91 \%$ Sp [143]. Novel quantitative US parameters from radiofrequency data analysis show promising results, surpassing the HRI [144].

Furthermore, numerous studies investigated the use of the novel CAP for steatosis evaluation, as a substitute for the invasive LB [145-147]. Several meta-analyses offered consistent results, with AUROC values ranging from $0.81-0.96$ for the detection of mild steatosis $(\geq S 1), 0.82-0.90$ for moderate steatosis $(\geq S 2)$, and $0.70-0.97$ for severe steatosis ( $\geq$ S3) [148-150]. In 2017, an individual patients' data meta-analysis, involving 2735 CLD subjects, provided cutoff values of $148 \mathrm{~dB} / \mathrm{m}, 286 \mathrm{~dB} / \mathrm{m}$ and $280 \mathrm{~dB} / \mathrm{m}$ for the presence of mild, moderate, and severe steatosis, respectively, using the M probe [23]. However, novel data suggests that optimal cutoff values vary significantly by both probes across different etiologies. Regarding HCV patients, the latest comprehensive meta-analysis could not analyze in great detail this pathology, due to the small cohort and low prevalence of high-grade steatosis [25]. Therefore, additional data concerning this etiology is still needed. Regarding performance, the Moret study found that the hepatorenal B-mode ratio and CAP have comparable power for the diagnosis of steatosis ( $\geq \mathrm{S} 1)$, but both lack the ability to discern between moderate to severe steatosis [151].

Moreover, studies show conflicting results with the use of CAP for steatosis evaluation in the context of the new DAA therapy. On one hand, Rout et al. [152] and Ogasawara et al. [153] reported that the CAP score tends to increase in patients treated with DAAs, but these studies could not find an explanation for this phenomenon. On the other hand, two other papers found that DAAs significantly lower hepatic steatosis in chronic HCV patients with fatty liver, while the Sung study noted significant steatosis reduction only in patients with moderate fatty infiltration (S0-S1) at baseline evaluation [154-156]. Nevertheless, CAP remains a powerful add-on in the management of HCV patients.

\section{Advantages and Limitations of VCTE}

Although VCTE is increasingly used in daily practice as a noninvasive and efficient method of assessing liver stiffness, it has several limitations. Technically, VCTE cannot be performed in patients with ascites because the elastic waves are not able to penetrate the fluids. Moreover, VCTE is limited by the narrow intercostal space and some obese patients present a challenge in the VCTE examination. In obese patients, the XL probe is required in order to reduce the failure rate $[10,26,48,157]$. Furthermore, in a multivariate analysis by Castera et al. [20], the only factor associated with failure was obesity (body mass index $>28 \mathrm{~kg} / \mathrm{m}^{2}, p<0.001$ ) and VCTE was not successful in $20 \%$ of cases. Other factors, such as abdominal wall edema or congestion, can alter the measurements and increase the stiffness, independently of fibrosis.

From another point of view, the main limitations are the need for a dedicated device, which is not always available, and the fact that it is not possible to choose a region of interest for the measurements. Individual factors related to the patient's condition, such as acute hepatitis, increased transaminases, extrahepatic cholestasis, congestion, and food or excessive alcohol intake could increase liver stiffness, resulting in false positive results [27]. 


\section{Concluding Remarks}

In the current paper, we have critically reviewed VCTE performance in the assessment of $\mathrm{HCV}$ patients, highlighting the advantages of this ultrasound elastographic technique in comparison to conventional US. Besides staging liver fibrosis, the high specificity and negative predictive value of VCTE suggest that it performs better at ruling out cirrhosis rather than diagnosing it. Furthermore, the high hierarchical summary receiver operating characteristic of VCTE in diagnosing CSPH proved the efficacy of this ultrasound elastography method in identifying CSPH. The current range of LS cutoff values for predicting the presence and size of the esophageal varices are wide and standardized values are not available. However, a general rule is that 'the greater the stiffness, the higher the possibility of esophageal varices and their diameter'. Whilst existing literature suggests that VCTE can be used for HCC risk prediction in other hepatopathies, there are currently no indications for risk prediction in HCV. This would be an important application, as VCTE already allows patient stratification through risk assessment in some instances. One of its upsides that opened a new era in $\mathrm{HCV}$ management is that it can be repeated every time it is deemed necessary-before antiviral therapy, in monitoring fibrosis regression after $\mathrm{HCV}$ eradication. As such, the advantages of VCTE significantly outweigh those of other surveillance methods.

Our opinion is that HCV patients can greatly benefit from VCTE due to its numerous qualities-rapid, noninvasive, repeatable for longitudinal evaluation and the costeffectiveness. We propose that further studies should focus on establishing standardized cutoff values of LS for predicting the presence and size of esophageal varices, as well as investigating the potential for predicting $\mathrm{HCC}$ risk in $\mathrm{HCV}$ patients, which is considered to be of great importance in current clinical practice.

Author Contributions: Conceptualization—all authors; writing-M.F., T.S., G.R.T., A.T.; writingreview—all authors; critically revising-M.L.-P., M.F.; project administration-M.L.-P. All authors have read and agreed to the published version of the manuscript.

Funding: This research received no external funding.

Conflicts of Interest: The authors declare no conflict of interest.

\section{References}

1. Ahmad, J. Hepatitis C. BMJ 2017, 358, j2861. [CrossRef]

2. Jafri, S.M.; Gordon, S.C. Epidemiology of Hepatitis C. Clin. Liver Dis. Hoboken 2018, 12, 140-142. [CrossRef]

3. Li, H.C.; Lo, S.Y. Hepatitis C virus: Virology, diagnosis and treatment. World J. Hepatol. 2015, 7, 1377-1389. [CrossRef]

4. Morozov, V.A.; Lagaye, S. Hepatitis C virus: Morphogenesis, infection and therapy. World J. Hepatol. 2018, 10, 186-212. [CrossRef]

5. Kennedy, P.; Wagner, M.; Castera, L.; Hong, C.W.; Johnson, C.L.; Sirlin, C.B.; Taouli, B. Quantitative Elastography Methods in Liver Disease: Current Evidence and Future Directions. Radiology 2018, 286, 738-763. [CrossRef]

6. Sirinawasatien, A.; Techasirioangkun, T. The Prevalence and Determinants of Hepatic Steatosis Assessed by Controlled Attenuation Parameter in Thai Chronic Hepatitis C Patients. Gastroenterol. Res. Pract. 2020, 2020, 8814135. [CrossRef] [PubMed]

7. Lupsor, M.; Badea, R.; Nedevschi, S.; Mitrea, D.; Florea, M. Ultrasonography Contribution to Hepatic Steatosis Quantification. Possibilities of Improving this Method through Computerized Analysis of Ultrasonic Image. In Proceedings of the 2006 IEEE International Conference on Automation, Quality and Testing, Robotics, Cluj-Napoca, Romania, 25-28 May 2006 ; pp. 478-483.

8. Trivedi, H.D.; Lin, S.C.; Lau, D.T.Y. Noninvasive Assessment of Fibrosis Regression in Hepatitis C Virus Sustained Virologic Responders. Gastroenterol. Hepatol. N. Y. 2017, 13, 587-595. [PubMed]

9. Seeff, L.B.; Everson, G.T.; Morgan, T.R.; Curto, T.M.; Lee, W.M.; Ghany, M.G.; Shiffman, M.L.; Fontana, R.J.; Di Bisceglie, A.M.; Bonkovsky, H.L.; et al. Complication rate of percutaneous liver biopsies among persons with advanced chronic liver disease in the HALT-C trial. Clin. Gastroenterol. Hepatol. 2010, 8, 877-883. [CrossRef]

10. Lupsor Platon, M.; Stefanescu, H.; Feier, D.; Maniu, A.; Badea, R. Performance of unidimensional transient elastography in staging chronic hepatitis C. Results from a cohort of 1202 biopsied patients from one single center. J. Gastrointestin Liver Dis. 2013, 22, 157-166. [PubMed]

11. Patel, K.; Sebastiani, G. Limitations of non-invasive tests for assessment of liver fibrosis. JHEP Rep. 2020, 2, 100067. [CrossRef]

12. Barr, R.G. Ultrasound of Diffuse Liver Disease Including Elastography. Radiol. Clin. N. Am. 2019, 57, 549-562. [CrossRef]

13. Zhang, G.L.; Zhao, Q.Y.; Lin, C.S.; Hu, Z.X.; Zhang, T.; Gao, Z.L. Transient Elastography and Ultrasonography: Optimal Evaluation of Liver Fibrosis and Cirrhosis in Patients with Chronic Hepatitis B Concurrent with Nonalcoholic Fatty Liver Disease. Biomed. Res. Int. 2019, 2019, 3951574. [CrossRef] [PubMed] 
14. Singh, T.; Allende, D.S.; McCullough, A.J. Assessing liver fibrosis without biopsy in patients with HCV or NAFLD. Cleve Clin. J. Med. 2019, 86, 179-186. [CrossRef] [PubMed]

15. Lupsor-Platon, M.; Serban, T.; Silion, A.I.; Tirpe, A.; Florea, M. Hepatocellular Carcinoma and Non-Alcoholic Fatty Liver Disease: A Step Forward for Better Evaluation Using Ultrasound Elastography. Cancers 2020, 12, 2778. [CrossRef]

16. Lupsor Platon, M. Noninvasive Assessment of Diffuse Liver Diseases Using Vibration-Controlled Transient Elastography (VCTE). In Ultrasound Elastography; IntechOpen: London, UK, 2019. [CrossRef]

17. Arena, U.; Lupsor Platon, M.; Stasi, C.; Moscarella, S.; Assarat, A.; Bedogni, G.; Piazzolla, V.; Badea, R.; Laffi, G.; Marra, F.; et al. Liver stiffness is influenced by a standardized meal in patients with chronic hepatitis $C$ virus at different stages of fibrotic evolution. Hepatology 2013, 58, 65-72. [CrossRef]

18. Tapper, E.B.; Castera, L.; Afdhal, N.H. FibroScan (vibration-controlled transient elastography): Where does it stand in the United States practice. Clin. Gastroenterol. Hepatol. 2015, 13, 27-36. [CrossRef]

19. Bonder, A.; Afdhal, N. Utilization of FibroScan in clinical practice. Curr. Gastroenterol. Rep. 2014, 16, 372. [CrossRef]

20. Castera, L.; Foucher, J.; Bernard, P.H.; Carvalho, F.; Allaix, D.; Merrouche, W.; Couzigou, P.; de Ledinghen, V. Pitfalls of liver stiffness measurement: A 5-year prospective study of 13,369 examinations. Hepatology 2010, 51, 828-835. [CrossRef]

21. Pang, J.X.; Pradhan, F.; Zimmer, S.; Niu, S.; Crotty, P.; Tracey, J.; Schneider, C.; Heitman, S.J.; Kaplan, G.G.; Swain, M.G.; et al. The feasibility and reliability of transient elastography using Fibroscan(R): A practice audit of 2335 examinations. Can. J. Gastroenterol. Hepatol. 2014, 28, 143-149. [CrossRef]

22. Tapper, E.B.; Afdhal, N.H. Vibration-controlled transient elastography: A practical approach to the noninvasive assessment of liver fibrosis. Curr. Opin. Gastroenterol. 2015, 31, 192-198. [CrossRef]

23. Karlas, T.; Petroff, D.; Sasso, M.; Fan, J.G.; Mi, Y.Q.; de Ledinghen, V.; Kumar, M.; Lupsor-Platon, M.; Han, K.H.; Cardoso, A.C.; et al. Individual patient data meta-analysis of controlled attenuation parameter (CAP) technology for assessing steatosis. $J$. Hepatol. 2017, 66, 1022-1030. [CrossRef]

24. Chon, Y.E.; Jung, K.S.; Kim, K.J.; Joo, D.J.; Kim, B.K.; Park, J.Y.; Kim, D.Y.; Ahn, S.H.; Han, K.H.; Kim, S.U. Normal controlled attenuation parameter values: A prospective study of healthy subjects undergoing health checkups and liver donors in Korea. Dig. Dis. Sci. 2015, 60, 234-242. [CrossRef] [PubMed]

25. Petroff, D.; Blank, V.; Newsome, P.N.; Shalimar, V.C.S.; Thiele, M.; de Lédinghen, V.; Baumeler, S.; Chan, W.K.; Perlemuter, G. Assessment of hepatic steatosis by controlled attenuation parameter using the M and XL probes: An individual patient data meta-analysis. Lancet Gastroenterol. Hepatol. 2021. [CrossRef]

26. Lupsor, M.; Badea, R.; Stefanescu, H.; Grigorescu, M.; Sparchez, Z.; Serban, A.; Branda, H.; Iancu, S.; Maniu, A. Analysis of histopathological changes that influence liver stiffness in chronic hepatitis C. Results from a cohort of 324 patients. J. Gastrointestin Liver Dis. 2008, 17, 155-163.

27. Dietrich, C.F.; Bamber, J.; Berzigotti, A.; Bota, S.; Cantisani, V.; Castera, L.; Cosgrove, D.; Ferraioli, G.; Friedrich-Rust, M.; Gilja, O.H.; et al. EFSUMB Guidelines and Recommendations on the Clinical Use of Liver Ultrasound Elastography, Update 2017 (Long Version). Ultraschall Med. 2017, 38, e16-e47. [CrossRef]

28. Adolf, S.; Millonig, G.; Friedrich, S.; Seitz, H.K.; Mueller, S. Valsalva and orthostatic maneuvers increase liver stiffness (Fibroscan $\left.{ }^{\circledR}\right)$ in healthy volunteers. Z. Gastroenterol. 2010, 48. [CrossRef]

29. Coco, B.; Oliveri, F.; Maina, A.M.; Ciccorossi, P.; Sacco, R.; Colombatto, P.; Bonino, F.; Brunetto, M.R. Transient elastography: A new surrogate marker of liver fibrosis influenced by major changes of transaminases. J. Viral. Hepat. 2007, 14, 360-369. [CrossRef]

30. Bota, S.; Sporea, I.; Peck-Radosavljevic, M.; Sirli, R.; Tanaka, H.; Iijima, H.; Saito, H.; Ebinuma, H.; Lupsor, M.; Badea, R.; et al. The influence of aminotransferase levels on liver stiffness assessed by Acoustic Radiation Force Impulse Elastography: A retrospective multicentre study. Dig. Liver Dis. 2013, 45, 762-768. [CrossRef]

31. Wang, J.H.; Changchien, C.S.; Hung, C.H.; Eng, H.L.; Tung, W.C.; Kee, K.M.; Chen, C.H.; Hu, T.H.; Lee, C.M.; Lu, S.N. FibroScan and ultrasonography in the prediction of hepatic fibrosis in patients with chronic viral hepatitis. J. Gastroenterol. 2009, 44, 439-446. [CrossRef]

32. Brener, S. Transient Elastography for Assessment of Liver Fibrosis and Steatosis: An Evidence-Based Analysis. Ont. Health Technol. Assess. Ser. 2015, 15, 1-45. [PubMed]

33. Sandrin, L.; Fourquet, B.; Hasquenoph, J.M.; Yon, S.; Fournier, C.; Mal, F.; Christidis, C.; Ziol, M.; Poulet, B.; Kazemi, F.; et al. Transient elastography: A new noninvasive method for assessment of hepatic fibrosis. Ultrasound Med. Biol. 2003, 29, $1705-1713$. [CrossRef]

34. Ziol, M.; Handra-Luca, A.; Kettaneh, A.; Christidis, C.; Mal, F.; Kazemi, F.; de Ledinghen, V.; Marcellin, P.; Dhumeaux, D.; Trinchet, J.C.; et al. Noninvasive assessment of liver fibrosis by measurement of stiffness in patients with chronic hepatitis C. Hepatology 2005, 41, 48-54. [CrossRef]

35. Castera, L.; Vergniol, J.; Foucher, J.; Le Bail, B.; Chanteloup, E.; Haaser, M.; Darriet, M.; Couzigou, P.; De Ledinghen, V. Prospective comparison of transient elastography, Fibrotest, APRI, and liver biopsy for the assessment of fibrosis in chronic hepatitis C. Gastroenterology 2005, 128, 343-350. [CrossRef]

36. De Ledinghen, V.; Douvin, C.; Kettaneh, A.; Ziol, M.; Roulot, D.; Marcellin, P.; Dhumeaux, D.; Beaugrand, M. Diagnosis of hepatic fibrosis and cirrhosis by transient elastography in HIV/hepatitis C virus-coinfected patients. J. Acquir. Immune Defic. Syndr. 2006, 41, 175-179. [CrossRef] 
37. Arena, U.; Vizzutti, F.; Abraldes, J.G.; Corti, G.; Stasi, C.; Moscarella, S.; Milani, S.; Lorefice, E.; Petrarca, A.; Romanelli, R.G.; et al. Reliability of transient elastography for the diagnosis of advanced fibrosis in chronic hepatitis C. Gut 2008, 57, 1288-1293. [CrossRef] [PubMed]

38. Zarski, J.P.; Sturm, N.; Guechot, J.; Paris, A.; Zafrani, E.S.; Asselah, T.; Boisson, R.C.; Bosson, J.L.; Guyader, D.; Renversez, J.C.; et al. Comparison of nine blood tests and transient elastography for liver fibrosis in chronic hepatitis C: The ANRS HCEP-23 study. J. Hepatol. 2012, 56, 55-62. [CrossRef] [PubMed]

39. Schwabl, P.; Bota, S.; Salzl, P.; Mandorfer, M.; Payer, B.A.; Ferlitsch, A.; Stift, J.; Wrba, F.; Trauner, M.; Peck-Radosavljevic, M.; et al. New reliability criteria for transient elastography increase the number of accurate measurements for screening of cirrhosis and portal hypertension. Liver Int. 2015, 35, 381-390. [CrossRef] [PubMed]

40. Yoneda, M.; Thomas, E.; Sclair, S.N.; Grant, T.T.; Schiff, E.R. Supersonic Shear Imaging and Transient Elastography With the XL Probe Accurately Detect Fibrosis in Overweight or Obese Patients With Chronic Liver Disease. Clin. Gastroenterol. Hepatol. 2015, 13, 1502-1509.e5. [CrossRef] [PubMed]

41. Njei, B.; McCarty, T.R.; Luk, J.; Ewelukwa, O.; Ditah, I.; Lim, J.K. Use of transient elastography in patients with HIV-HCV coinfection: A systematic review and meta-analysis. J. Gastroenterol. Hepatol. 2016, 31, 1684-1693. [CrossRef]

42. Sanchez-Conde, M.; Montes-Ramirez, M.L.; Miralles, P.; Alvarez, J.M.; Bellon, J.M.; Ramirez, M.; Arribas, J.R.; Gutierrez, I.; Lopez, J.C.; Cosin, J.; et al. Comparison of transient elastography and liver biopsy for the assessment of liver fibrosis in HIV/hepatitis C virus-coinfected patients and correlation with noninvasive serum markers. J. Viral. Hepat. 2010, 17, 280-286. [CrossRef]

43. Nitta, Y.; Kawabe, N.; Hashimoto, S.; Harata, M.; Komura, N.; Kobayashi, K.; Arima, Y.; Shimazaki, H.; Nakano, T.; Murao, M.; et al. Liver stiffness measured by transient elastography correlates with fibrosis area in liver biopsy in patients with chronic hepatitis C. Hepatol. Res. 2009, 39, 675-684. [CrossRef]

44. Poynard, T.; Halfon, P.; Castera, L.; Munteanu, M.; Imbert-Bismut, F.; Ratziu, V.; Benhamou, Y.; Bourliere, M.; de Ledinghen, V.; FibroPaca, G. Standardization of ROC curve areas for diagnostic evaluation of liver fibrosis markers based on prevalences of fibrosis stages. Clin. Chem. 2007, 53, 1615-1622. [CrossRef]

45. Carrion, J.A.; Navasa, M.; Bosch, J.; Bruguera, M.; Gilabert, R.; Forns, X. Transient elastography for diagnosis of advanced fibrosis and portal hypertension in patients with hepatitis C recurrence after liver transplantation. Liver Transpl. 2006, 12, 1791-1798. [CrossRef] [PubMed]

46. Sporea, I.; Sirli, R.; Deleanu, A.; Tudora, A.; Curescu, M.; Cornianu, M.; Lazar, D. Comparison of the liver stiffness measurement by transient elastography with the liver biopsy. World J. Gastroenterol. 2008, 14, 6513-6517. [CrossRef]

47. Reiberger, T.; Ferlitsch, A.; Payer, B.A.; Pinter, M.; Schwabl, P.; Stift, J.; Trauner, M.; Peck-Radosavljevic, M. Noninvasive screening for liver fibrosis and portal hypertension by transient elastography-A large single center experience. Wien. Klin. Wochenschr. 2012, 124, 395-402. [CrossRef]

48. European Association for Study of Liver; Asociacion Latinoamericana para el Estudio del Higado. EASL-ALEH Clinical Practice Guidelines: Non-invasive tests for evaluation of liver disease severity and prognosis. J. Hepatol. 2015, 63, 237-264. [CrossRef]

49. Talwalkar, J.A.; Kurtz, D.M.; Schoenleber, S.J.; West, C.P.; Montori, V.M. Ultrasound-based transient elastography for the detection of hepatic fibrosis: Systematic review and meta-analysis. Clin. Gastroenterol. Hepatol. 2007, 5, 1214-1220. [CrossRef]

50. Shaheen, A.A.; Wan, A.F.; Myers, R.P. FibroTest and FibroScan for the prediction of hepatitis C-related fibrosis: A systematic review of diagnostic test accuracy. Am. J. Gastroenterol. 2007, 102, 2589-2600. [CrossRef]

51. Stebbing, J.; Farouk, L.; Panos, G.; Anderson, M.; Jiao, L.R.; Mandalia, S.; Bower, M.; Gazzard, B.; Nelson, M. A meta-analysis of transient elastography for the detection of hepatic fibrosis. J. Clin. Gastroenterol. 2010, 44, 214-219. [CrossRef]

52. Tsochatzis, E.A.; Gurusamy, K.S.; Ntaoula, S.; Cholongitas, E.; Davidson, B.R.; Burroughs, A.K. Elastography for the diagnosis of severity of fibrosis in chronic liver disease: A meta-analysis of diagnostic accuracy. J. Hepatol. 2011, 54, 650-659. [CrossRef]

53. Ying, H.Y.; Lu, L.G.; Jing, D.D.; Ni, X.S. Accuracy of transient elastography in the assessment of chronic hepatitis C-related liver cirrhosis. Clin. Investig. Med. 2016, 39, E150-E160. [CrossRef]

54. Colletta, C.; Smirne, C.; Fabris, C.; Toniutto, P.; Rapetti, R.; Minisini, R.; Pirisi, M. Value of two noninvasive methods to detect progression of fibrosis among HCV carriers with normal aminotransferases. Hepatology 2005, 42, 838-845. [CrossRef]

55. Moon, K.M.; Kim, G.; Baik, S.K.; Choi, E.; Kim, M.Y.; Kim, H.A.; Cho, M.Y.; Shin, S.Y.; Kim, J.M.; Park, H.J.; et al. Ultrasonographic scoring system score versus liver stiffness measurement in prediction of cirrhosis. Clin. Mol. Hepatol. 2013, 19, 389-398. [CrossRef] [PubMed]

56. Berzigotti, A.; Abraldes, J.G.; Tandon, P.; Erice, E.; Gilabert, R.; Garcia-Pagan, J.C.; Bosch, J. Ultrasonographic evaluation of liver surface and transient elastography in clinically doubtful cirrhosis. J. Hepatol. 2010, 52, 846-853. [CrossRef]

57. Gunarathne, L.S.; Rajapaksha, H.; Shackel, N.; Angus, P.W.; Herath, C.B. Cirrhotic portal hypertension: From pathophysiology to novel therapeutics. World J. Gastroenterol. 2020, 26, 6111-6140. [CrossRef]

58. Bosch, J.; Abraldes, J.G.; Berzigotti, A.; Garcia-Pagan, J.C. The clinical use of HVPG measurements in chronic liver disease. Nat. Rev. Gastroenterol. Hepatol. 2009, 6, 573-582. [CrossRef]

59. Shi, K.Q.; Fan, Y.C.; Pan, Z.Z.; Lin, X.F.; Liu, W.Y.; Chen, Y.P.; Zheng, M.H. Transient elastography: A meta-analysis of diagnostic accuracy in evaluation of portal hypertension in chronic liver disease. Liver Int. 2013, 33, 62-71. [CrossRef]

60. Papatheodoridi, M.; Hiriart, J.B.; Lupsor-Platon, M.; Bronte, F.; Boursier, J.; Elshaarawy, O.; Marra, F.; Thiele, M.; Markakis, G.; Payance, A.; et al. Refining the Baveno VI elastography criteria for the definition of compensated advanced chronic liver disease. J. Hepatol. 2021, 74, 1109-1116. [CrossRef] 
61. Berzigotti, A.; Piscaglia, F.; Education, E.; Professional Standards, C. Ultrasound in portal hypertension-Part 2-And EFSUMB recommendations for the performance and reporting of ultrasound examinations in portal hypertension. Ultraschall Med. 2012, 33, 8-32; quiz 30-31. [CrossRef] [PubMed]

62. Berzigotti, A.; Piscaglia, F. Ultrasound in portal hypertension-Part 1. Ultraschall Med. 2011, 32, 548-568; quiz 569-571. [CrossRef]

63. Kim, M.Y.; Baik, S.K.; Park, D.H.; Lim, D.W.; Kim, J.W.; Kim, H.S.; Kwon, S.O.; Kim, Y.J.; Chang, S.J.; Lee, S.S. Damping index of Doppler hepatic vein waveform to assess the severity of portal hypertension and response to propranolol in liver cirrhosis: A prospective nonrandomized study. Liver Int. 2007, 27, 1103-1110. [CrossRef] [PubMed]

64. Cannella, R.; Giambelluca, D.; Pellegrinelli, A.; Cabassa, P. Color Doppler Ultrasound in Portal Hypertension: A Closer Look at Left Gastric Vein Hemodynamics. J. Ultrasound Med. 2021, 40, 7-14. [CrossRef]

65. Bolognesi, M.; Sacerdoti, D.; Merkel, C.; Bombonato, G.; Gatta, A. Noninvasive grading of the severity of portal hypertension in cirrhotic patients by echo-color-Doppler. Ultrasound Med. Biol. 2001, 27, 901-907. [CrossRef]

66. Lee, C.M.; Jeong, W.K.; Lim, S.; Kim, Y.; Kim, J.; Kim, T.Y.; Sohn, J.H. Diagnosis of Clinically Significant Portal Hypertension in Patients with Cirrhosis: Splenic Arterial Resistive Index versus Liver Stiffness Measurement. Ultrasound Med. Biol. 2016, 42, 1312-1320. [CrossRef]

67. Qi, X.; Berzigotti, A.; Cardenas, A.; Sarin, S.K. Emerging non-invasive approaches for diagnosis and monitoring of portal hypertension. Lancet Gastroenterol. Hepatol. 2018, 3, 708-719. [CrossRef]

68. Llop, E.; Berzigotti, A.; Reig, M.; Erice, E.; Reverter, E.; Seijo, S.; Abraldes, J.G.; Bruix, J.; Bosch, J.; Garcia-Pagan, J.C. Assessment of portal hypertension by transient elastography in patients with compensated cirrhosis and potentially resectable liver tumors. $J$. Hepatol. 2012, 56, 103-108. [CrossRef]

69. Hong, W.K.; Kim, M.Y.; Baik, S.K.; Shin, S.Y.; Kim, J.M.; Kang, Y.S.; Lim, Y.L.; Kim, Y.J.; Cho, Y.Z.; Hwang, H.W.; et al. The usefulness of non-invasive liver stiffness measurements in predicting clinically significant portal hypertension in cirrhotic patients: Korean data. Clin. Mol. Hepatol. 2013, 19, 370-375. [CrossRef]

70. Augustin, S.; Millan, L.; Gonzalez, A.; Martell, M.; Gelabert, A.; Segarra, A.; Serres, X.; Esteban, R.; Genesca, J. Detection of early portal hypertension with routine data and liver stiffness in patients with asymptomatic liver disease: A prospective study. $J$. Hepatol. 2014, 60, 561-569. [CrossRef]

71. Kitson, M.T.; Roberts, S.K.; Colman, J.C.; Paul, E.; Button, P.; Kemp, W. Liver stiffness and the prediction of clinically significant portal hypertension and portal hypertensive complications. Scand. J. Gastroenterol. 2015, 50, 462-469. [CrossRef]

72. Zykus, R.; Jonaitis, L.; Petrenkiene, V.; Pranculis, A.; Kupcinskas, L. Liver and spleen transient elastography predicts portal hypertension in patients with chronic liver disease: A prospective cohort study. BMC Gastroenterol. 2015, 15, 183. [CrossRef] [PubMed]

73. Procopet, B.; Berzigotti, A.; Abraldes, J.G.; Turon, F.; Hernandez-Gea, V.; Garcia-Pagan, J.C.; Bosch, J. Real-time shear-wave elastography: Applicability, reliability and accuracy for clinically significant portal hypertension. J. Hepatol. 2015, 62, 1068-1075. [CrossRef]

74. Kumar, A.; Khan, N.M.; Anikhindi, S.A.; Sharma, P.; Bansal, N.; Singla, V.; Arora, A. Correlation of transient elastography with hepatic venous pressure gradient in patients with cirrhotic portal hypertension: A study of 326 patients from India. World J. Gastroenterol. 2017, 23, 687-696. [CrossRef] [PubMed]

75. Vizzutti, F.; Arena, U.; Romanelli, R.G.; Rega, L.; Foschi, M.; Colagrande, S.; Petrarca, A.; Moscarella, S.; Belli, G.; Zignego, A.L.; et al. Liver stiffness measurement predicts severe portal hypertension in patients with HCV-related cirrhosis. Hepatology 2007, 45, 1290-1297. [CrossRef]

76. Bureau, C.; Metivier, S.; Peron, J.M.; Selves, J.; Robic, M.A.; Gourraud, P.A.; Rouquet, O.; Dupuis, E.; Alric, L.; Vinel, J.P. Transient elastography accurately predicts presence of significant portal hypertension in patients with chronic liver disease. Aliment. Pharm. 2008, 27, 1261-1268. [CrossRef] [PubMed]

77. Lemoine, M.; Katsahian, S.; Ziol, M.; Nahon, P.; Ganne-Carrie, N.; Kazemi, F.; Grando-Lemaire, V.; Trinchet, J.C.; Beaugrand, M. Liver stiffness measurement as a predictive tool of clinically significant portal hypertension in patients with compensated hepatitis C virus or alcohol-related cirrhosis. Aliment. Pharm. 2008, 28, 1102-1110. [CrossRef]

78. Sanchez-Conde, M.; Miralles, P.; Bellon, J.M.; Rincon, D.; Ramirez, M.; Gutierrez, I.; Ripoll, C.; Lopez, J.C.; Cosin, J.; Clemente, G.; et al. Use of transient elastography (FibroScan(R)) for the noninvasive assessment of portal hypertension in HIV/HCV-coinfected patients. J. Viral Hepat. 2011, 18, 685-691. [CrossRef]

79. Vergniol, J.; Foucher, J.; Terrebonne, E.; Bernard, P.H.; le Bail, B.; Merrouche, W.; Couzigou, P.; de Ledinghen, V. Noninvasive tests for fibrosis and liver stiffness predict 5-year outcomes of patients with chronic hepatitis C. Gastroenterology 2011, 140, 1970-1979.e3. [CrossRef] [PubMed]

80. Kim, B.K.; Fung, J.; Yuen, M.F.; Kim, S.U. Clinical application of liver stiffness measurement using transient elastography in chronic liver disease from longitudinal perspectives. World J. Gastroenterol. 2013, 19, 1890-1900. [CrossRef] [PubMed]

81. Poynard, T.; Vergniol, J.; Ngo, Y.; Foucher, J.; Munteanu, M.; Merrouche, W.; Colombo, M.; Thibault, V.; Schiff, E.; Brass, C.A.; et al. Staging chronic hepatitis $\mathrm{C}$ in seven categories using fibrosis biomarker (FibroTest) and transient elastography (FibroScan(R)). J. Hepatol. 2014, 60, 706-714. [CrossRef] [PubMed]

82. Robic, M.A.; Procopet, B.; Metivier, S.; Peron, J.M.; Selves, J.; Vinel, J.P.; Bureau, C. Liver stiffness accurately predicts portal hypertension related complications in patients with chronic liver disease: A prospective study. J. Hepatol. 2011, 55, 1017-1024. [CrossRef] 
83. Tseng, Y.; Li, F.; Wang, J.; Chen, S.; Jiang, W.; Shen, X.; Wu, S. Spleen and liver stiffness for noninvasive assessment of portal hypertension in cirrhotic patients with large esophageal varices. J. Clin. Ultrasound 2018, 46, 442-449. [CrossRef]

84. Marasco, G.; Colecchia, A.; Colli, A.; Ravaioli, F.; Casazza, G.; Bacchi Reggiani, M.L.; Cucchetti, A.; Cescon, M.; Festi, D. Role of liver and spleen stiffness in predicting the recurrence of hepatocellular carcinoma after resection. J. Hepatol. 2019, 70, 440-448. [CrossRef]

85. Hu, X.; Huang, X.; Hou, J.; Ding, L.; Su, C.; Meng, F. Diagnostic accuracy of spleen stiffness to evaluate portal hypertension and esophageal varices in chronic liver disease: A systematic review and meta-analysis. Eur. Radiol. 2021, 31, 2392-2404. [CrossRef]

86. Kazemi, F.; Kettaneh, A.; N'Kontchou, G.; Pinto, E.; Ganne-Carrie, N.; Trinchet, J.C.; Beaugrand, M. Liver stiffness measurement selects patients with cirrhosis at risk of bearing large oesophageal varices. J. Hepatol. 2006, 45, 230-235. [CrossRef]

87. Berzigotti, A.; Seijo, S.; Arena, U.; Abraldes, J.G.; Vizzutti, F.; Garcia-Pagan, J.C.; Pinzani, M.; Bosch, J. Elastography, spleen size, and platelet count identify portal hypertension in patients with compensated cirrhosis. Gastroenterology 2013, 144, 102-111.e1. [CrossRef]

88. De Franchis, R.; Baveno, V.I.F. Expanding consensus in portal hypertension: Report of the Baveno VI Consensus Workshop: Stratifying risk and individualizing care for portal hypertension. J. Hepatol. 2015, 63, 743-752. [CrossRef] [PubMed]

89. Jiang, H.Y.; Chen, J.; Xia, C.C.; Cao, L.K.; Duan, T.; Song, B. Noninvasive imaging of hepatocellular carcinoma: From diagnosis to prognosis. World J. Gastroenterol. 2018, 24, 2348-2362. [CrossRef] [PubMed]

90. Marrero, J.A.; Kulik, L.M.; Sirlin, C.B.; Zhu, A.X.; Finn, R.S.; Abecassis, M.M.; Roberts, L.R.; Heimbach, J.K. Diagnosis, Staging, and Management of Hepatocellular Carcinoma: 2018 Practice Guidance by the American Association for the Study of Liver Diseases. Hepatology 2018, 68, 723-750. [CrossRef] [PubMed]

91. Segura Grau, A.; Valero Lopez, I.; Diaz Rodriguez, N.; Segura Cabral, J.M. Liver ultrasound: Focal lesions and diffuse diseases. Semergen 2016, 42, 307-314. [CrossRef]

92. Lupsor-Platon, M.; Serban, T.; Silion, A.I.; Tirpe, G.R.; Tirpe, A.; Florea, M. Performance of Ultrasound Techniques and the Potential of Artificial Intelligence in the Evaluation of Hepatocellular Carcinoma and Non-Alcoholic Fatty Liver Disease. Cancers 2021, 13, 790. [CrossRef]

93. Yoshida, H.; Shiratori, Y.; Moriyama, M.; Arakawa, Y.; Ide, T.; Sata, M.; Inoue, O.; Yano, M.; Tanaka, M.; Fujiyama, S.; et al. Interferon therapy reduces the risk for hepatocellular carcinoma: National surveillance program of cirrhotic and noncirrhotic patients with chronic hepatitis C in Japan. IHIT Study Group. Inhibition of Hepatocarcinogenesis by Interferon Therapy. Ann. Intern. Med. 1999, 131, 174-181. [CrossRef] [PubMed]

94. Masuzaki, R.; Tateishi, R.; Yoshida, H.; Goto, E.; Sato, T.; Ohki, T.; Imamura, J.; Goto, T.; Kanai, F.; Kato, N.; et al. Prospective risk assessment for hepatocellular carcinoma development in patients with chronic hepatitis $\mathrm{C}$ by transient elastography. Hepatology 2009, 49, 1954-1961. [CrossRef] [PubMed]

95. Kuo, Y.H.; Lu, S.N.; Hung, C.H.; Kee, K.M.; Chen, C.H.; Hu, T.H.; Lee, C.M.; Changchien, C.S.; Wang, J.H. Liver stiffness measurement in the risk assessment of hepatocellular carcinoma for patients with chronic hepatitis. Hepatol. Int. 2010, 4, 700-706. [CrossRef]

96. Feier, D.; Lupsor Platon, M.; Stefanescu, H.; Badea, R. Transient elastography for the detection of hepatocellular carcinoma in viral C liver cirrhosis. Is there something else than increased liver stiffness? J. Gastrointestin Liver Dis. 2013, 22, 283-289. [PubMed]

97. Akima, T.; Tamano, M.; Hiraishi, H. Liver stiffness measured by transient elastography is a predictor of hepatocellular carcinoma development in viral hepatitis. Hepatol. Res. 2011, 41, 965-970. [CrossRef] [PubMed]

98. Wang, H.M.; Hung, C.H.; Lu, S.N.; Chen, C.H.; Lee, C.M.; Hu, T.H.; Wang, J.H. Liver stiffness measurement as an alternative to fibrotic stage in risk assessment of hepatocellular carcinoma incidence for chronic hepatitis C patients. Liver Int. 2013, 33, 756-761. [CrossRef] [PubMed]

99. Narita, Y.; Genda, T.; Tsuzura, H.; Sato, S.; Kanemitsu, Y.; Ishikawa, S.; Kikuchi, T.; Hirano, K.; Iijima, K.; Wada, R.; et al. Prediction of liver stiffness hepatocellular carcinoma in chronic hepatitis $\mathrm{C}$ patients on interferon-based anti-viral therapy. J. Gastroenterol. Hepatol. 2014, 29, 137-143. [CrossRef]

100. Kim, D.Y.; Song, K.J.; Kim, S.U.; Yoo, E.J.; Park, J.Y.; Ahn, S.H.; Han, K.H. Transient elastography-based risk estimation of hepatitis B virus-related occurrence of hepatocellular carcinoma: Development and validation of a predictive model. Oncotargets 2013, 6, 1463-1469. [CrossRef]

101. Wong, G.L.; Chan, H.L.; Wong, C.K.; Leung, C.; Chan, C.Y.; Ho, P.P.; Chung, V.C.; Chan, Z.C.; Tse, Y.K.; Chim, A.M.; et al. Liver stiffness-based optimization of hepatocellular carcinoma risk score in patients with chronic hepatitis B. J. Hepatol. 2014, 60, 339-345. [CrossRef]

102. Lee, H.W.; Ahn, S.H. Prediction models of hepatocellular carcinoma development in chronic hepatitis B patients. World J. Gastroenterol. 2016, 22, 8314-8321. [CrossRef]

103. Lee, H.W.; Park, S.Y.; Lee, M.; Lee, E.J.; Lee, J.; Kim, S.U.; Park, J.Y.; Kim, D.Y.; Ahn, S.H.; Kim, B.K. An optimized hepatocellular carcinoma prediction model for chronic hepatitis B with well-controlled viremia. Liver Int. 2020, 40, 1736-1743. [CrossRef] [PubMed]

104. Seo, Y.S.; Jang, B.K.; Um, S.H.; Hwang, J.S.; Han, K.H.; Kim, S.G.; Lee, K.S.; Kim, S.U.; Kim, Y.S.; Lee, J.I. Validation of risk prediction models for the development of HBV-related HCC: A retrospective multi-center 10-year follow-up cohort study. Oncotarget 2017, 8, 113213-113224. [CrossRef] [PubMed] 
105. Cheung, M.C.M.; Walker, A.J.; Hudson, B.E.; Verma, S.; McLauchlan, J.; Mutimer, D.J.; Brown, A.; Gelson, W.T.H.; MacDonald, D.C.; Agarwal, K.; et al. Outcomes after successful direct-acting antiviral therapy for patients with chronic hepatitis $\mathrm{C}$ and decompensated cirrhosis. J. Hepatol. 2016, 65, 741-747. [CrossRef] [PubMed]

106. Romano, A.; Angeli, P.; Piovesan, S.; Noventa, F.; Anastassopoulos, G.; Chemello, L.; Cavalletto, L.; Gambato, M.; Russo, F.P.; Burra, P.; et al. Newly diagnosed hepatocellular carcinoma in patients with advanced hepatitis C treated with DAAs: A prospective population study. J. Hepatol. 2018, 69, 345-352. [CrossRef]

107. Ioannou, G.N.; Green, P.K.; Berry, K. HCV eradication induced by direct-acting antiviral agents reduces the risk of hepatocellular carcinoma. J. Hepatol. 2017. [CrossRef]

108. Morgan, R.L.; Baack, B.; Smith, B.D.; Yartel, A.; Pitasi, M.; Falck-Ytter, Y. Eradication of hepatitis C virus infection and the development of hepatocellular carcinoma: A meta-analysis of observational studies. Ann. Intern. Med. 2013, 158, 329-337. [CrossRef]

109. ANRS Collaborative Study Group. Lack of evidence of an effect of direct-acting antivirals on the recurrence of hepatocellular carcinoma: Data from three ANRS cohorts. J. Hepatol. 2016, 65, 734-740. [CrossRef]

110. Kanwal, F.; Kramer, J.; Asch, S.M.; Chayanupatkul, M.; Cao, Y.; El-Serag, H.B. Risk of Hepatocellular Cancer in HCV Patients Treated With Direct-Acting Antiviral Agents. Gastroenterology 2017, 153, 996-1005.e1. [CrossRef]

111. Stasi, C.; Sadalla, S.; Carradori, E.; Monti, M.; Petraccia, L.; Madia, F.; Gragnani, L.; Zignego, A.L. Longitudinal evaluation of liver stiffness and outcomes in patients with chronic hepatitis $C$ before and after short- and long-term IFN-free antiviral treatment. Curr. Med. Res. Opin. 2020, 36, 245-249. [CrossRef]

112. Ravaioli, F.; Conti, F.; Brillanti, S.; Andreone, P.; Mazzella, G.; Buonfiglioli, F.; Serio, I.; Verrucchi, G.; Bacchi Reggiani, M.L.; Colli, A.; et al. Hepatocellular carcinoma risk assessment by the measurement of liver stiffness variations in HCV cirrhotics treated with direct acting antivirals. Dig. Liver Dis. 2018, 50, 573-579. [CrossRef]

113. Ioannou, G.N.; Green, P.K.; Beste, L.A.; Mun, E.J.; Kerr, K.F.; Berry, K. Development of models estimating the risk of hepatocellular carcinoma after antiviral treatment for hepatitis C. J. Hepatol. 2018, 69, 1088-1098. [CrossRef] [PubMed]

114. Strazzulla, A.; Iemmolo, R.M.R.; Carbone, E.; Postorino, M.C.; Mazzitelli, M.; De Santis, M.; Di Benedetto, F.; Cristiani, C.M.; Costa, C.; Pisani, V.; et al. The Risk of Hepatocellular Carcinoma After Directly Acting Antivirals for Hepatitis C Virus Treatment in Liver Transplanted Patients: Is It Real? Hepat. Mon. 2016, 16, e41933. [CrossRef]

115. Masuzaki, R.; Yamashiki, N.; Sugawara, Y.; Yoshida, H.; Tateishi, R.; Tamura, S.; Kaneko, J.; Hasegawa, K.; Kokudo, N.; Makuuchi, M.; et al. Assessment of liver stiffness in patients after living donor liver transplantation by transient elastography. Scand. J. Gastroenterol. 2009, 44, 1115-1120. [CrossRef]

116. Knop, V.; Hoppe, D.; Welzel, T.; Vermehren, J.; Herrmann, E.; Vermehren, A.; Friedrich-Rust, M.; Sarrazin, C.; Zeuzem, S.; Welker, M.W. Regression of fibrosis and portal hypertension in HCV-associated cirrhosis and sustained virologic response after interferon-free antiviral therapy. J. Viral. Hepat. 2016, 23, 994-1002. [CrossRef]

117. Ogawa, E.; Furusyo, N.; Toyoda, K.; Takeoka, H.; Maeda, S.; Hayashi, J. The longitudinal quantitative assessment by transient elastography of chronic hepatitis $\mathrm{C}$ patients treated with pegylated interferon alpha-2b and ribavirin. Antivir. Res. 2009, 83, 127-134. [CrossRef] [PubMed]

118. Arima, Y.; Kawabe, N.; Hashimoto, S.; Harata, M.; Nitta, Y.; Murao, M.; Nakano, T.; Shimazaki, H.; Kobayashi, K.; Ichino, N.; et al. Reduction of liver stiffness by interferon treatment in the patients with chronic hepatitis C. Hepatol. Res. 2010, 40, 383-392. [CrossRef] [PubMed]

119. Macias, J.; del Valle, J.; Rivero, A.; Mira, J.A.; Camacho, A.; Merchante, N.; Perez-Camacho, I.; Neukam, K.; Rivero-Juarez, A.; Mata, R.; et al. Changes in liver stiffness in patients with chronic hepatitis $\mathrm{C}$ with and without HIV co-infection treated with pegylated interferon plus ribavirin. J. Antimicrob. Chemother. 2010, 65, 2204-2211. [CrossRef] [PubMed]

120. Wang, J.H.; Changchien, C.S.; Hung, C.H.; Tung, W.C.; Kee, K.M.; Chen, C.H.; Hu, T.H.; Lee, C.M.; Lu, S.N. Liver stiffness decrease after effective antiviral therapy in patients with chronic hepatitis C: Longitudinal study using FibroScan. J. Gastroenterol. Hepatol. 2010, 25, 964-969. [CrossRef]

121. Hezode, C.; Castera, L.; Roudot-Thoraval, F.; Bouvier-Alias, M.; Rosa, I.; Roulot, D.; Leroy, V.; Mallat, A.; Pawlotsky, J.M. Liver stiffness diminishes with antiviral response in chronic hepatitis C. Aliment. Pharm. 2011, 34, 656-663. [CrossRef]

122. Martinez, S.M.; Foucher, J.; Combis, J.M.; Metivier, S.; Brunetto, M.; Capron, D.; Bourliere, M.; Bronowicki, J.P.; Dao, T.; MaynardMuet, M.; et al. Longitudinal liver stiffness assessment in patients with chronic hepatitis $\mathrm{C}$ undergoing antiviral therapy. PLoS ONE 2012, 7, e47715. [CrossRef]

123. Stasi, C.; Arena, U.; Zignego, A.L.; Corti, G.; Monti, M.; Triboli, E.; Pellegrini, E.; Renzo, S.; Leoncini, L.; Marra, F.; et al. Longitudinal assessment of liver stiffness in patients undergoing antiviral treatment for hepatitis C. Dig. Liver Dis. 2013, 45, 840-843. [CrossRef]

124. Persico, M.; Rosato, V.; Aglitti, A.; Precone, D.; Corrado, M.; De Luna, A.; Morisco, F.; Camera, S.; Federico, A.; Dallio, M.; et al. Sustained virological response by direct antiviral agents in HCV leads to an early and significant improvement of liver fibrosis. Antivir. Ther. 2018, 23, 129-138. [CrossRef] [PubMed]

125. Chan, J.; Gogela, N.; Zheng, H.; Lammert, S.; Ajayi, T.; Fricker, Z.; Kim, A.Y.; Robbins, G.K.; Chung, R.T. Direct-Acting Antiviral Therapy for Chronic HCV Infection Results in Liver Stiffness Regression Over 12 Months Post-treatment. Dig. Dis. Sci. 2018, 63, 486-492. [CrossRef] 
126. Giannini, E.G.; Crespi, M.; Demarzo, M.; Bodini, G.; Furnari, M.; Marabotto, E.; Torre, F.; Zentilin, P.; Savarino, V. Improvement in hepatitis $C$ virus patients with advanced, compensated liver disease after sustained virological response to direct acting antivirals. Eur. J. Clin. Investig. 2019, 49, e13056. [CrossRef] [PubMed]

127. Martinez-Camprecios, J.; Bonis Puig, S.; Pons Delgado, M.; Salcedo Allende, M.T.; Minguez Rosique, B.; Genesca Ferrer, J. Transient elastography in DAA era. Relation between post-SVR LSM and histology. J. Viral. Hepat. 2020, 27, 453-455. [CrossRef]

128. Knop, V.; Mauss, S.; Goeser, T.; Geier, A.; Zimmermann, T.; Herzer, K.; Postel, N.; Friedrich-Rust, M.; Hofmann, W.P.; German Hepatitis, C.R. Dynamics of liver stiffness by transient elastography in patients with chronic hepatitis $C$ virus infection receiving direct-acting antiviral therapy-Results from the German Hepatitis C-Registry. J. Viral Hepat. 2020, 27, 690-698. [CrossRef] [PubMed]

129. McPhail, J.; Sims, O.T.; Guo, Y.; Wooten, D.; Herndon, J.S.; Massoud, O.I. Fibrosis improvement in patients with HCV treated with direct-acting antivirals. Eur. J. Gastroenterol. Hepatol. 2020. [CrossRef]

130. Tada, T.; Kumada, T.; Toyoda, H.; Mizuno, K.; Sone, Y.; Kataoka, S.; Hashinokuchi, S. Improvement of liver stiffness in patients with hepatitis $C$ virus infection who received direct-acting antiviral therapy and achieved sustained virological response. $J$. Gastroenterol. Hepatol. 2017, 32, 1982-1988. [CrossRef]

131. Bachofner, J.A.; Valli, P.V.; Kroger, A.; Bergamin, I.; Kunzler, P.; Baserga, A.; Braun, D.; Seifert, B.; Moncsek, A.; Fehr, J.; et al. Direct antiviral agent treatment of chronic hepatitis $C$ results in rapid regression of transient elastography and fibrosis markers fibrosis-4 score and aspartate aminotransferase-platelet ratio index. Liver Int. 2017, 37, 369-376. [CrossRef] [PubMed]

132. Tachi, Y.; Hirai, T.; Kojima, Y.; Ishizu, Y.; Honda, T.; Kuzuya, T.; Hayashi, K.; Ishigami, M.; Goto, H. Liver stiffness reduction correlates with histological characteristics of hepatitis C patients with sustained virological response. Liver Int. 2018, 38, 59-67. [CrossRef]

133. Rockey, D.C. Fibrosis reversal after hepatitis C virus elimination. Curr. Opin. Gastroenterol. 2019, 35, 137-144. [CrossRef] [PubMed]

134. D'Ambrosio, R.; Aghemo, A.; Rumi, M.G.; Ronchi, G.; Donato, M.F.; Paradis, V.; Colombo, M.; Bedossa, P. A morphometric and immunohistochemical study to assess the benefit of a sustained virological response in hepatitis $C$ virus patients with cirrhosis. Hepatology 2012, 56, 532-543. [CrossRef] [PubMed]

135. Goossens, N.; Negro, F. Is genotype 3 of the hepatitis C virus the new villain? Hepatology 2014, 59, 2403-2412. [CrossRef] [PubMed]

136. Asselah, T.; Rubbia-Brandt, L.; Marcellin, P.; Negro, F. Steatosis in chronic hepatitis C: Why does it really matter? Gut 2006, 55, 123-130. [CrossRef]

137. Castera, L.; Hezode, C.; Roudot-Thoraval, F.; Bastie, A.; Zafrani, E.S.; Pawlotsky, J.M.; Dhumeaux, D. Worsening of steatosis is an independent factor of fibrosis progression in untreated patients with chronic hepatitis C and paired liver biopsies. Gut 2003, 52, 288-292. [CrossRef] [PubMed]

138. Kurosaki, M.; Hosokawa, T.; Matsunaga, K.; Hirayama, I.; Tanaka, T.; Sato, M.; Yasui, Y.; Tamaki, N.; Ueda, K.; Tsuchiya, K.; et al. Hepatic steatosis in chronic hepatitis $\mathrm{C}$ is a significant risk factor for developing hepatocellular carcinoma independent of age, sex, obesity, fibrosis stage and response to interferon therapy. Hepatol. Res. 2010, 40, 870-877. [CrossRef]

139. Leandro, G.; Mangia, A.; Hui, J.; Fabris, P.; Rubbia-Brandt, L.; Colloredo, G.; Adinolfi, L.E.; Asselah, T.; Jonsson, J.R.; Smedile, A.; et al. Relationship between steatosis, inflammation, and fibrosis in chronic hepatitis C: A meta-analysis of individual patient data. Gastroenterology 2006, 130, 1636-1642. [CrossRef]

140. Fartoux, L.; Chazouilleres, O.; Wendum, D.; Poupon, R.; Serfaty, L. Impact of steatosis on progression of fibrosis in patients with mild hepatitis C. Hepatology 2005, 41, 82-87. [CrossRef]

141. Stern, C.; Castera, L. Non-invasive diagnosis of hepatic steatosis. Hepatol. Int. 2017, 11, 70-78. [CrossRef]

142. Hernaez, R.; Lazo, M.; Bonekamp, S.; Kamel, I.; Brancati, F.L.; Guallar, E.; Clark, J.M. Diagnostic accuracy and reliability of ultrasonography for the detection of fatty liver: A meta-analysis. Hepatology 2011, 54, 1082-1090. [CrossRef]

143. Webb, M.; Yeshua, H.; Zelber-Sagi, S.; Santo, E.; Brazowski, E.; Halpern, Z.; Oren, R. Diagnostic value of a computerized hepatorenal index for sonographic quantification of liver steatosis. AJR Am. J. Roentgenol. 2009, 192, 909-914. [CrossRef]

144. Jeon, S.K.; Joo, I.; Kim, S.Y.; Jang, J.K.; Park, J.; Park, H.S.; Lee, E.S.; Lee, J.M. Quantitative ultrasound radiofrequency data analysis for the assessment of hepatic steatosis using the controlled attenuation parameter as a reference standard. Ultrasonography 2021, 40, 136-146. [CrossRef]

145. Sasso, M.; Tengher-Barna, I.; Ziol, M.; Miette, V.; Fournier, C.; Sandrin, L.; Poupon, R.; Cardoso, A.C.; Marcellin, P.; Douvin, C.; et al. Novel controlled attenuation parameter for noninvasive assessment of steatosis using Fibroscan((R)): Validation in chronic hepatitis C. J. Viral. Hepat. 2012, 19, 244-253. [CrossRef]

146. Ferraioli, G.; Tinelli, C.; Lissandrin, R.; Zicchetti, M.; Dal Bello, B.; Filice, G.; Filice, C. Controlled attenuation parameter for evaluating liver steatosis in chronic viral hepatitis. World J. Gastroenterol. 2014, 20, 6626-6631. [CrossRef]

147. De Ledinghen, V.; Vergniol, J.; Foucher, J.; Merrouche, W.; le Bail, B. Non-invasive diagnosis of liver steatosis using controlled attenuation parameter (CAP) and transient elastography. Liver Int. 2012, 32, 911-918. [CrossRef]

148. Mi, Y.Q.; Shi, Q.Y.; Xu, L.; Shi, R.F.; Liu, Y.G.; Li, P.; Shen, F.; Lu, W.; Fan, J.G. Controlled attenuation parameter for noninvasive assessment of hepatic steatosis using Fibroscan(R): Validation in chronic hepatitis B. Dig. Dis. Sci. 2015, 60, 243-251. [CrossRef]

149. Wang, Y.; Fan, Q.; Wang, T.; Wen, J.; Wang, H.; Zhang, T. Controlled attenuation parameter for assessment of hepatic steatosis grades: A diagnostic meta-analysis. Int. J. Clin. Exp. Med. 2015, 8, 17654-17663. [PubMed] 
150. Pu, K.; Wang, Y.; Bai, S.; Wei, H.; Zhou, Y.; Fan, J.; Qiao, L. Diagnostic accuracy of controlled attenuation parameter (CAP) as a non-invasive test for steatosis in suspected non-alcoholic fatty liver disease: A systematic review and meta-analysis. BMC Gastroenterol. 2019, 19, 51. [CrossRef]

151. Moret, A.; Boursier, J.; Houssel Debry, P.; Riou, J.; Crouan, A.; Dubois, M.; Michalak Provost, S.; Aube, C.; Paisant, A. Evaluation of the Hepatorenal B-Mode Ratio and the "Controlled Attenuation Parameter" for the Detection and Grading of Steatosis. Ultraschall Med. 2020. [CrossRef]

152. Rout, G.; Nayak, B.; Patel, A.H.; Gunjan, D.; Singh, V.; Kedia, S. Therapy with Oral Directly Acting Agents in Hepatitis C Infection Is Associated with Reduction in Fibrosis and Increase in Hepatic Steatosis on Transient Elastography. J. Clin. Exp. Hepatol. 2019, 9, 207-214. [CrossRef] [PubMed]

153. Ogasawara, N.; Kobayashi, M.; Akuta, N.; Kominami, Y.; Fujiyama, S.; Kawamura, Y.; Sezaki, H.; Hosaka, T.; Suzuki, F.; Saitoh, S.; et al. Serial changes in liver stiffness and controlled attenuation parameter following direct-acting antiviral therapy against hepatitis C virus genotype 1b. J. Med. Virol. 2018, 90, 313-319. [CrossRef] [PubMed]

154. Kobayashi, N.; Iijima, H.; Tada, T.; Kumada, T.; Yoshida, M.; Aoki, T.; Nishimura, T.; Nakano, C.; Takata, R.; Yoh, K.; et al. Changes in liver stiffness and steatosis among patients with hepatitis $C$ virus infection who received direct-acting antiviral therapy and achieved sustained virological response. Eur. J. Gastroenterol. Hepatol. 2018, 30, 546-551. [CrossRef] [PubMed]

155. Shimizu, K.; Soroida, Y.; Sato, M.; Hikita, H.; Kobayashi, T.; Endo, M.; Sato, M.; Gotoh, H.; Iwai, T.; Tateishi, R.; et al. Eradication of hepatitis $\mathrm{C}$ virus is associated with the attenuation of steatosis as evaluated using a controlled attenuation parameter. Sci. Rep. 2018, 8, 7845. [CrossRef] [PubMed]

156. Sung, J.C.; Wyatt, B.E.; Perumalswami, P.V.; Branch, A.D. Response to 'hepatitis C cure improved patient-reported outcomes in patients with and without liver fibrosis in a prospective study at a large urban medical center'. J. Viral. Hepat. 2020, 27, 1502-1503. [CrossRef] [PubMed]

157. Ferraioli, G.; Filice, C.; Castera, L.; Choi, B.I.; Sporea, I.; Wilson, S.R.; Cosgrove, D.; Dietrich, C.F.; Amy, D.; Bamber, J.C.; et al. WFUMB guidelines and recommendations for clinical use of ultrasound elastography: Part 3: Liver. Ultrasound Med. Biol. 2015, 41, 1161-1179. [CrossRef] [PubMed] 